Author: Professor lain S. Stewart

Affiliation: Royal Scientific Society, 70 Ahmad Al Tarawneh St, Al Jubaiha, Amman, JORDAN

Email: iain.stewart@rss.jo

This article is a non-peer reviewed preprint submitted to EarthArXiv.

The article has been submitted for consideration to the Jordan Journal of Earth \& Environmental Sciences and is currently under review. 


\section{Integrating the 'the triangle of geography, geology and geophysics' into sustainable development}

lain S. Stewart

Royal Scientific Society, 70 Ahmad Al Tarawneh St, Al Jubaiha, Amman, JORDAN Contact email: iain.stewart@rss.jo

\section{ABSTRACT}

In the context of tackling climate change in the eastern Mediterranean and Middle East, HRH Prince El-Hassan bin Talal has called for an integrated approach to human and natural resources management that takes account of 'the triangle of geography, geology and geophysics'. The lack of application of geoscientific knowledge to sustainable development issues is surprising given that advancing human progress lies at the roots of modern geoscience and aligns with the intellectual mindsets and technical skills that geoscientists are trained in. Applying this Earth science toolkit to the challenges of longterm sustainability will require the global geoscience community to repurpose its principles and practices, in particular: (1) better communicating what geoscientists know and do, and how that is socially useful; (2) reaching out to other disciplines more engaged in sustainability issues; and (3) re-designing Earth science education and training programmes to place sustainability and human wellbeing at the heart of a $21^{\text {st }}$ century geoscientist's professional purpose.

Keywords: geoscience; sustainability; Sustainable Development Goals; human wellbeing 


\section{Introduction}

In his opening address to the 2020 "Climate Change in the Eastern Mediterranean and the Middle East" symposium organized by the Jordanian Atomic Energy Commission, HRH Prince El-Hassan bin Talal called for regional measures and solutions in the Middle East and the eastern Mediterranean basin to strengthen scientific and technological cooperation at the policy level in facing the climate change challenge ${ }^{1}$. As part of that strategic planning, Prince El Hassan stressed the importance of an integrated approach to human and natural resources management, ${ }^{\prime} . .$. taking into account the triangle of geography, geology and geophysics'.

It is welcome but rare to hear a global statesman highlight the critical role of geoscience in sustainable development. As acknowledged in Prince El Hassan's remarks, the '3Gs' of (physical) geography, geology and geophysics remain underrepresented in relation to other disciplines in contributing knowledge and expertise to regional and global concerns over planetary health and human wellbeing (Mora 2013, Stewart \& Gill 2017). This 'invisibility' of geoscience in sustainable development discourse is surprising because the social mission of human advancement exists deep in the historical roots of contemporary geoscience. Two centuries ago, distilled by socially-progressive Enlightenment thinking, James Hutton placed the 'physiology' of the planet at the heart of a new integrated and holistic Earth science amid the technological birth of Britain's industrial revolution. His seminal 1788 opus 'Theory of the Earth' opened with the remark 'This globe of the earth is a habitable world, and on its fitness for this purpose, our sense of wisdom in its formation must depend' (Hutton 1788, p.). The subsequent refinement of modern Earth

\footnotetext{
${ }^{1}$ Prince El-Hassan urges scientific, tech cooperation to counter climate change challenge Jordan Times, 30 September 2020 https://www.petra.gov.jo/Include/InnerPage.jsp?|D=28711\&lang=en\&name=en_news
} 
science has only served to reinforce its intellectual credentials as a science that 'looks forwards backwards' to advance human progress (Lucchesi 2017, Rajendran 2019).

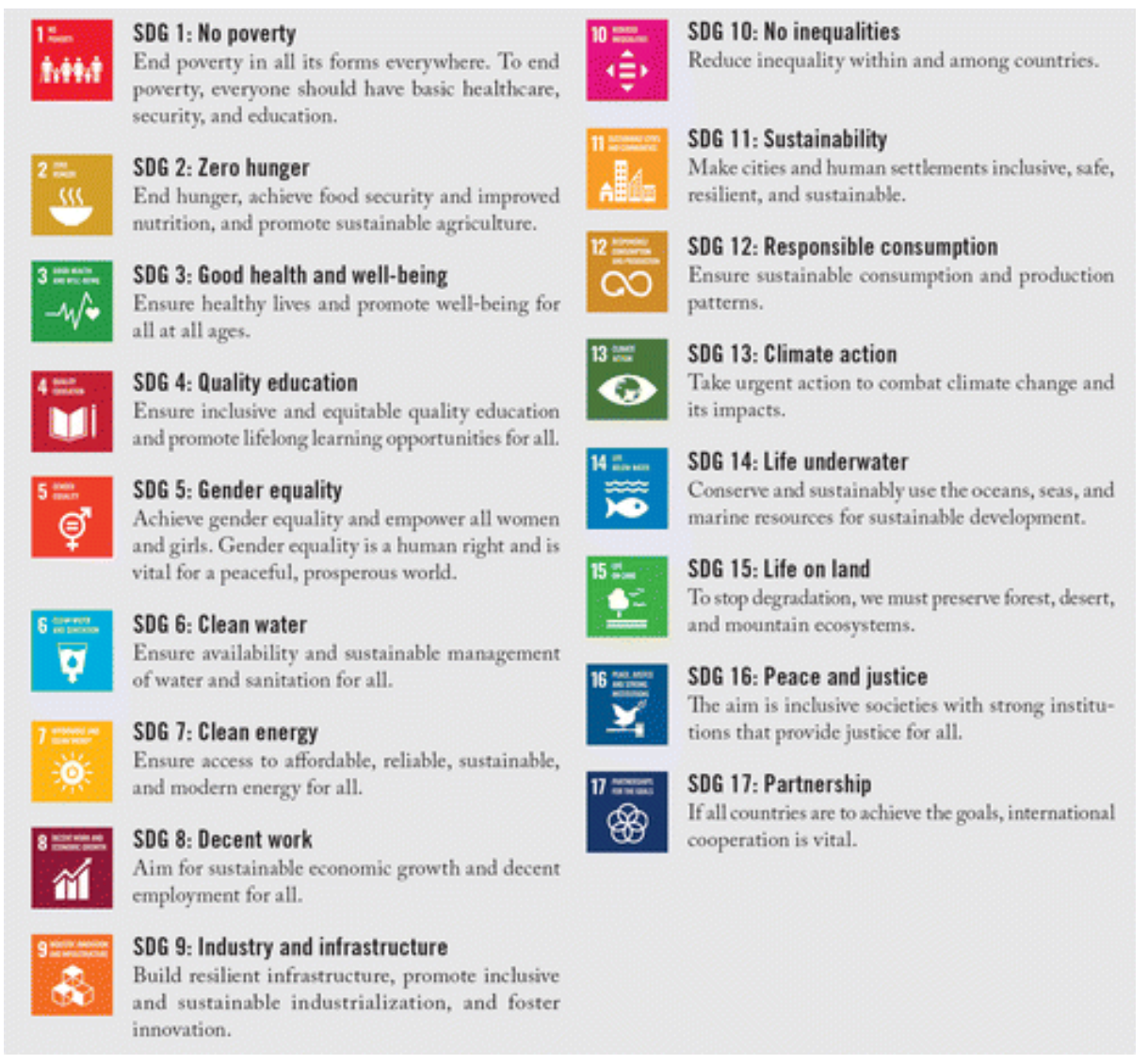

Fig. 1: The 2015-2030 United Nations Sustainable Development Goals

This article sets out the contextual background to Prince El Hassan's provocation and examines the contributions that geoscience and geoscientists might bring to the principles and practices of sustainable development. In doing that, it advances several key challenges that the geoscience community will need to address in order to effectively engage in the global sustainability agenda.

\section{The Challenges Ahead}

Our planet, or more specifically those living on it, will face a gathering storm of 'grand challenges' in the $21^{\text {st }}$ century. Those challenges arise from global socio-economic drivers 
of international trade, industrialisation and urbanisation, as a growing human population consumes its natural resource base at an ever-accelerating pace and tackles a consequent climatic and ecological crisis that imperils humanity's ultimate survival. Geoscience - the study of our planet's 4.5 billion year old history, how it works, and what it means for those living on it - potentially offers important knowledge, experience, and guidance on how to confront many of these critical challenges (Schlosser \& Pfirman 2012, Gill 2017, Stewart \& Gill 2017) (Fig 1). Despite its traditional focus on looking backwards into 'deep time', geological input now seems essential for forward-looking sustainable stewardship of the planet (Beer et al. 2018). Geoscientific expertise is needed for ensuring the material supply for the 'energy transition' to renewable technologies and supporting the wider 'clean, green economy' that major countries are moving towards to, responding to increasing water and food insecurity crises in regions suffering the effects of climate change, tackling the ecological ravages of habitat destruction and biodiversity loss, and reducing the risk of disasters in the world's swelling urban centres.

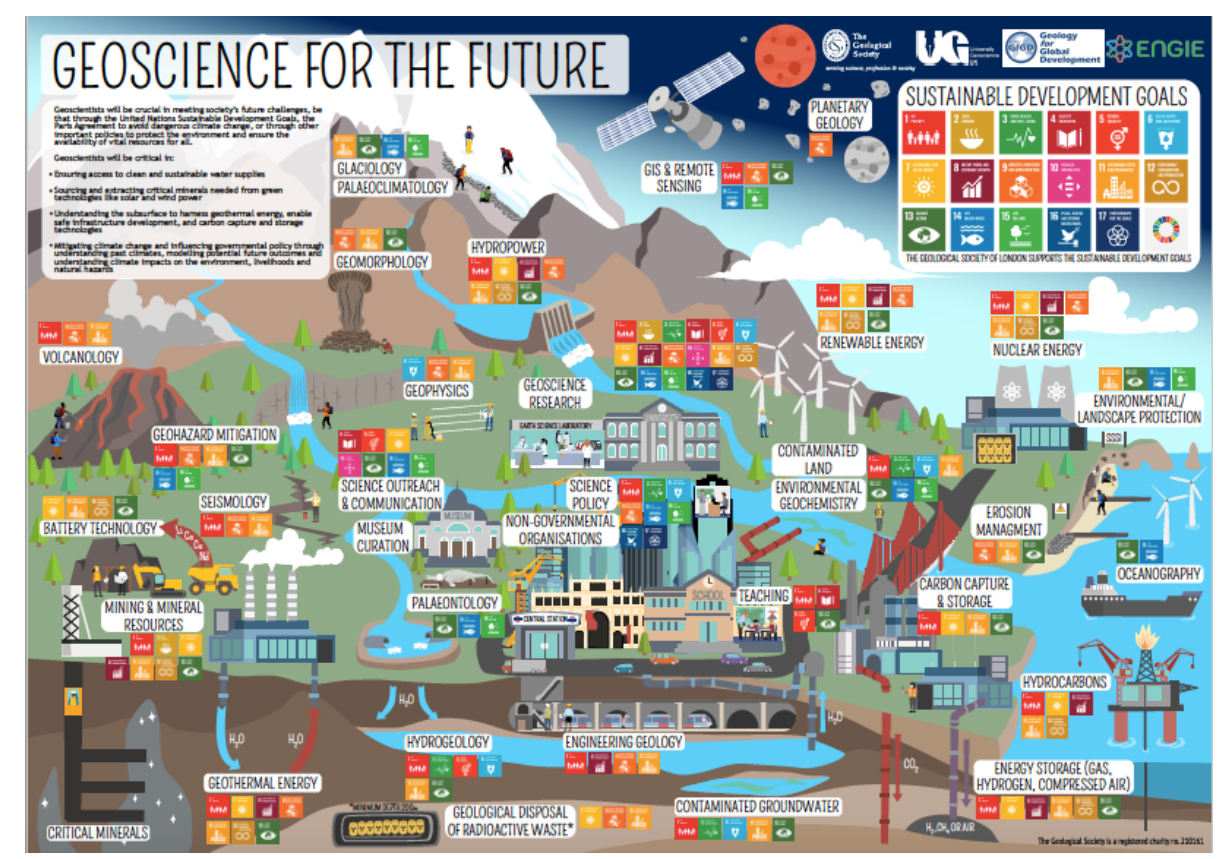

Fig 2: A promotional poster from the Geological Society of London, available in multiple languages, highlighting the diversity of contributions that geoscientists can make to society. 
The urgent imperative for Earth science to help address society's growing unsustainability gains deeper motivation from the perversity that humans themselves have become a dominant geological force, now sufficient in intensity to warrant our own bespoke era: the Anthropocene (Steffen et al. 2011, Crutzen 2016, Zalasiewicz et al. 2019). Although the conceptual space for creating the modern Anthropocene was carved during the nineteenth-century foundation of geology (Davis 2011), geoscientific methods designed to unravel 'deep time' now track the environmental and ecological fallout from presentday human actions. The Huttonian science in which 'the present is the key to the past' now looks forwards to provide guidance on planetary boundaries, earth system tipping points, and 'a safe operating space for humanity' (Rockstrom et al. 2009). The fact that some of the cumulative impacts of our anthropogenic changes are now significant enough to be able to be compared with natural analogues in the geological past (Burke et al. 2018) means that now, more than ever before, the central tenets of 'palaeoscience' bear directly on future society (Mills \& Jones 2021.

Entering this new 'human age', geoscience's direction of travel seems clear. Although 'discovery science' about our planet's distant geological past will continue, '... Earth sciences research needs to be more focused on problem solving rather than refining our knowledge of the problems that face the Earth system' (Ludden 2020, p.69). Traditional applied geological and geophysical fields (economic geology, petroleum geology, engineering geology, hydrogeology, geohazards) will assume even greater importance, alongside the more geographical facets of climate science, land management and disaster risk reduction. Increasingly, society will look to the geosciences not only for sustainably providing its resource demands (Lambert 2001) but also resolving the impact of developmental projects on the environment, the severity of natural hazards, and human health. Even very basic geological and environmental know-how can help transform resource-poor communities and tackle development barriers in many regions 
(Gill et al. 2019), and economic livelihoods can be improved directly through geoheritage and geo-tourism, such as UNESCO Geo-parks (Catana \& Brilha 2020).

In countless ways, sustainable stewardship of the planet will benefit from a more explicitly acknowledgement of the critical importance of the natural world's underpinning 'geodiversity' (Schrodt et al. 2019). So, with that mission in mind, what are the specific key skillsets and mindsets that geoscientists can bring to the global sustainability agenda?

\section{The Sustainable Geoscience Toolkit}

Geoscientists are Earth scientists, meaning that their core concern is the fundamental working of the planet. They do that through a multidisciplinary science that integrates physics, chemistry and biology, draws from engineering, computing and mathematics, and spills over into the geographical and environmental sciences (Fig. 3).

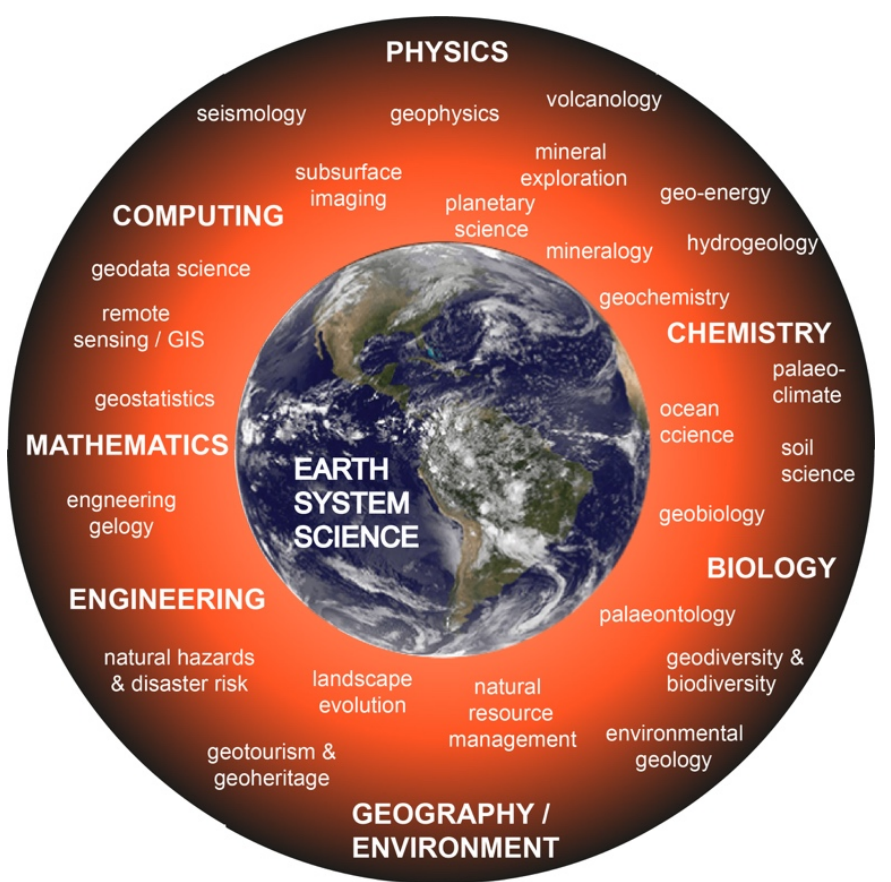

Fig 3: The multidisciplinary nature of geoscience, integrating physics, chemistry and biology and drawing from engineering, mathematics and geography 
Blending and balancing these disparate disciplines develops high-level competency across a broad portfolio of technical specialisms, notably:

- geophysics - deploys a wide array of techniques that image inside the planet's depths and monitor the action of earthquakes (seismology) and volcanoes (volcanology).

- geochemistry - where the tools and principles of chemistry are used to forensically characterise the materials, minerals and rocks that make up our physical world (mineralogy and petrology).

- geobiology- reveals the intimate relations between environments and ecosystems, past and present, and charts the evolution of life as preserved in the rock record (palaeontology).

- engineering geology- uses our understanding of soil and rock properties to solve practical problems for infrastructure and the built environment whilst hydrogeology examines the flow of groundwater in the subsurface.

- geodata science uses probability and statistics to measure of Earth variables over time and space, and high-level mathematical modelling and computation tools alongside Artificial Intelligence and Machine Learning to solve and visualize complex planetary problems.

In combining these disparate disciplines into a coherent mode of planetary inquiry, geoscience manages to balance and blend a suite of complementary methodological mindsets (Frodeman 1995, Clelland 2001, Baker 2014). These are:

- Geoscience as an interpretative science: indirect, ambiguous, enigmatic and subjective clues in the rock record or the deep subsurface need to be deciphered to shed light on Earth processes (Curtis 2012) 
- Geoscience as an observational science: observations play a central role in geoscientists' reasoning and testing of new ideas and theories (Rogers 1989, Kastens et al. 2009)

- Geoscience as a historical science: observations of present-day phenomena and environments are used to infer conditions in the past (Frodeman 1995, Dodick \& Orion 2003)

- Geoscience as a 'big data' science: vast volumes of data have informed geological inquiry but the 'digital revolution' promises a new era of data-driven geoscientific discovery (Pennington et al. 2020, Stephenson et al. 2020, Wang et al 2020)

- Geoscience as systems science: recognizing the dynamic interconnections that maintain a habitable planet (Clark et al. 2004, Stillings 2006)

Geoscientists understand that the Earth is a system integrating the solid earth (lithosphere) and the other 'spheres' (atmos, hydro, cryo and bio) and that feedbacks between these constituent parts are critical for sustainability (Clark et al. 2004). Earth systems are "complex" in the technical sense: exhibiting nonlinear interactions, multiple stable states, fractal and chaotic behavior, self-organized criticality, and non-Gaussian distributions of outputs. But they are also "complicated" in the ordinary sense of the word; multiple processes (mechanical, chemical, biological, and anthropogenic) may operate and interact at the same time and place. Although geoscientists are not the only scientists who work with complicated, complex systems, their ability and propensity to apply a systems approach to understanding the Earth across multiple scales is an important expertise that geoscientists offer society. As Gosselin et al. (2013) notes, 'As a historical and interpretative science, geology can inform society about interactions in coupled human-environmental systems because our skills and proficiencies allow us to recognize the varying manifestations of phenomena at different spatial and temporal scales. 
These intellectual and technical competencies are fairly well known and accepted within the geoscience community (though much less so beyond), but arguably it is our lesser appreciated conceptual and creative thinking skills that may be the most valuable to sustainable development. As the pioneering petroleum geologist Wallace Pratt pointed out decades ago "Where oil is first found, in the final analysis, is in the minds of men" (Pratt, 1952). The human mind is arguably the geoscientist's most important tool (Rajendran 2019). It is the geoscience mind that '...converts colors and textures of dirt, or blotches on a satellite image, or wiggles on a seismogram, into explanatory narratives about the formation and migration of oil, the rise and fall of mountain ranges, the opening and closing of oceans' (Kastens et al. 2009, p.265).

Geoscientists also take a long view of time, appreciating the relative brevity of human history within the vastness of the age of the Earth (Orion 2006). This perspective is unusual: short time frames, of the order of days to years, drive most decisions in business, politics, and media news cycles. If widely adopted, geoscientists' more attenuated view of time might provide a crucial counterweight, and support decision making with a time horizon of decades to centuries. What's more, in their guise as time travelers, geoscientists can envision Earth in states drastically different from the planet that currently exists, a perceptive skill that in turn draws on other key conceptual skillsets (Manduca \& Mowk 2006, Kastens 2009, Kastens \& Manduca 2012):

- interdisciplinary problem solving: geoscientists solve problems in the context of an open and dynamic system of interacting parts and processes

- managing uncertainty: geoscientists revel in incomplete data and subjectivity, probability and uncertainty are integral to all geoscience interpretations

- 3D \& 4D thinking: being able to visualize and solve problems in three dimensions and across time requires geoscientists to have considerable intellectual flexibility, imagination and creativity (Reynolds 2012) 
- multi-scalar levels of inquiry: geoscientists span from the nanoscale to the planetary scale to understand how the Earth works

- geoscience reasoning and synthesis: geoscientists apply a very particular form of scientific reasoning, recognising that most geological problems have no clear, unambiguous answers and working by analogy and inference to make predictions with limited data (Frodeman 1995, 2014, Clelland 2001, Baker 2014)

- working in the real-world 'laboratory': field-based learning helps geoscientists develop a feel for Earth processes and a sense of scale, and strengthens their ability to integrate messy, fragmentary information, reason spatially and temporally, and critique the quality of observational data.

Although much modern geoscientific analysis is undertaken in the laboratory or imaged from space, $21^{\text {st }}$ century geoscience remains at its traditional core a field-based science. In undertaking reconnaisance geological mapping and geophysical exploration, geoscientists are often the first 'boots on the ground'. They are, therefore, generally the initial interface between their organisations and local neighbourhoods and communities, and with securing the 'social licence to operate' a critical part of publically-contested infrastructure, minerals and energy development projects, communication is an implicit geoscience skill (Stewart \& Lewis 2017). Although generally a 'soft skill' in which they are rarely formally trained, geoscientists find themselves on a daily basis explaining their science to other technical specialists and other professionals, translating partial and obscure data and observations into coherent narratives that link past, present and future. In that regard, geoscientists are natural storytellers, routinely developing compelling narratives to explain our often abstract ideas about the deep Earth or ancient worlds (Stewart \& Nield 2013).

None of these technical, conceptual and social skills, taken individually, is unique to geoscience. Nor does every individual geoscientist have every one of these skills or apply them in their work. But taken collectively, this combination of attributes provides a 
powerful toolkit for addressing the uncertain and untested problems of sustainable development. With that recognition, many national geological surveys are already reformulating their strategies around sustainable geosciences principles and practices (Smelror 2020, Ludden 2021). At the same time, the key professional sectors that geoscience serves are also rapidly adjusting, with the construction, minerals extraction, and energy sectors increasingly projecting themselves, their practices, and their people through the lens of sustainability and the Sustainable Development Goals framework (Capella et al. 2017, Calas et al. 2017, Mudd 2021) (Fig 4).

Whether geoscientists like it or not, a brave new world is rapidly coming. And yet, despite the signs that a new Earth sciences revolution is underway, the academic geoscience community in universities and research institutes around the world still appear to remain wedded to traditional $20^{\text {th }}$ century Earth science pedagogies and practices. So, what needs to change?

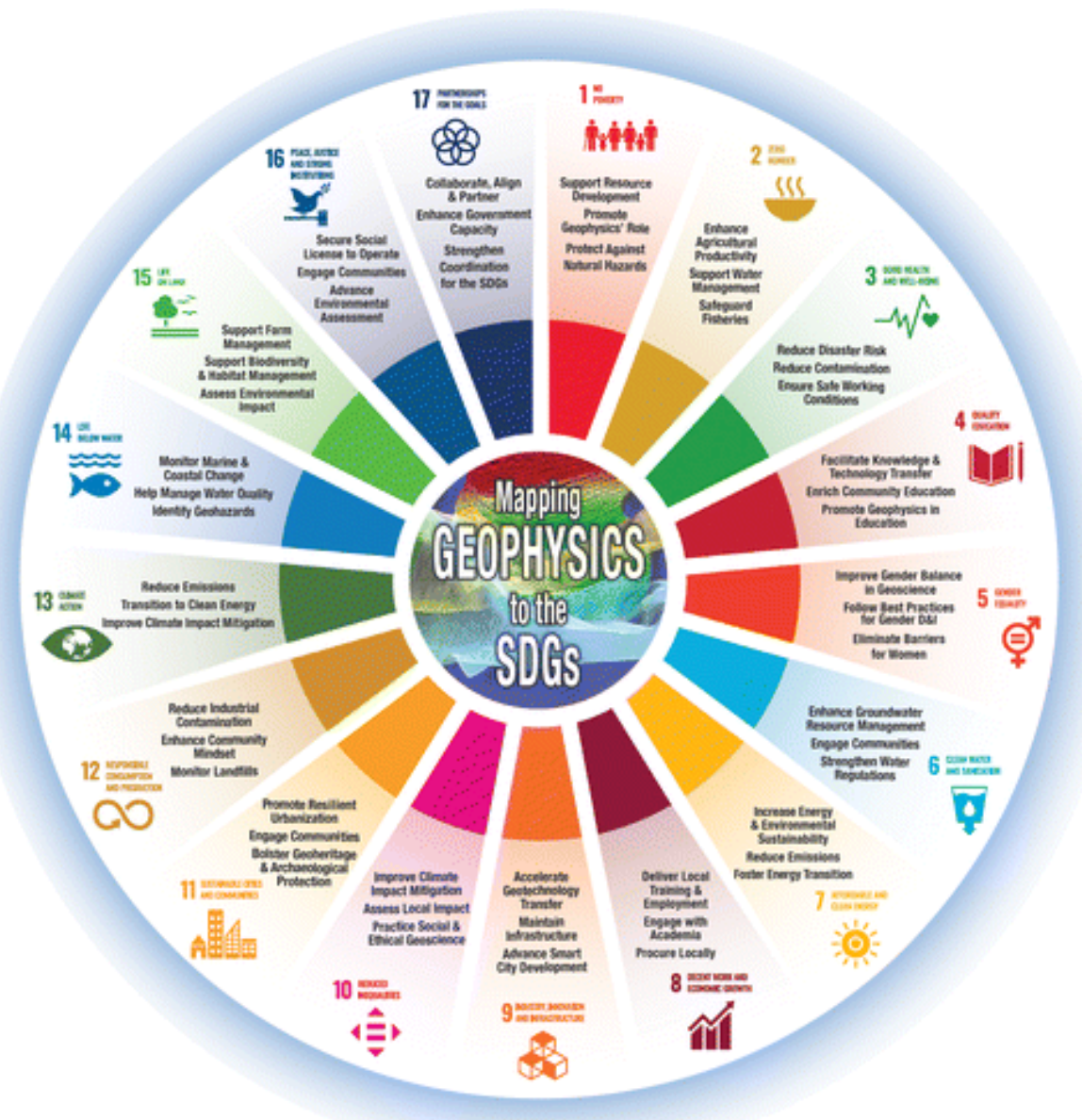


Fig. 4: The Geophysics Sustainability Wheel (Capella et al. 2017)

\section{Looking Forward Backwards}

The challenge from Prince El Hassan about how the triangle of geography, geology and geophysics can be integrated effectively into national and regional sustainability agendas presents a critical question for modern geoscience. Currently, too few geoscientists have direct involvement in the growing societal shift towards achieving the 2030 UN Sustainable Development Goals (Schlosser \& Pfirman 2012, Mora et al. 2013, Stewart 2016). 'Sustainability' and 'sustainable development' rarely featured in many university geoscience courses or professional geoscientific training, and the topic is largely absent from Earth science research in specialist journals or academic conferences (Stewart \& Gill 2017). At the individual level, many geoscientists can (and do) make more direct contributions to sustainable development. However, at the strategic level of the global geoscience community, three 'missions' seem paramount:

1. Geoscience needs to better communicate what it knows, what it does, and why it is useful.

2. Geoscience needs to reach out to other disciplines more engaged in sustainability issues

3. Geoscience needs to re-design its education and training programmes to place sustainability and human wellbeing at the core of their professional purpose.

\subsection{The Communication Challenge}

Outside of long-suffering wives, husbands and partners, few non-geologists know what geoscience is. There is a general sense that geology is rocks ('stones') and fossils ('dinosaurs'), but the harsh reality is that beyond that ordinary people pay little attention to and have no interest in the wider Earth sciences realm (Stewart \& Nield 2013). And so, 
if the average person in the street has little or no grasp of what a geologist is or does, then why should a local government official, business executive or policy maker have any better idea?

Traditionally, there has been an academic disinterest and an institutional lack of incentive to encourage scientists to translate their technical science for non-technical audiences (Stewart \& Lewis 2017). That, however, is no longer the case. More and more, national governments, through their funding agencies, are demanding public accountability for research funds, and the response has been a dramatic increase in university support for science communication training and for academics taking part in associated public engagement and educational outreach activity. As part of that sector-wide academic mindshift, geoscientists around the world are being expected not just to undertake geological investigations but to justify why their work is important and tell end-users what it means for them. It is a change that geoscientist should embrace because, as highlighted above, most are natural storytellers and the subject of the Earth, its extraordinary history, and its present-day impact on those living on it provides a rich diet for popular science consumption (Stewart \& Nield 2013). But 'selling planet earth' to publics and policymakers will require more than just strengthening our geoscience outreach activity, but rather will require the systemic embedding of the science (and art) of science communication into our graduate, postgraduate and early-career training programmes (Stewart \& Hurth 2021).

\subsection{The Interdisciplinary Challenge}

Addressing complex and contested sustainability issues requires a broad coalition of disciplines as solutions can not be determined by mono-disciplinary advances. Geoscience, by default, is itself a multidisciplinary field of inquiry (Fig 5) but wider crossdisciplinary collaborations are required. In the first comprehensive overview of geology for sustainable development, the Geological Survey of India stressed the need for 
geologists, geochemists, geophysicists, geomorphologists and the like to work together in integrated projects with engineers and planners (GSI 2010). Such collaborations are now fairly commonplace, and there are encouraging signs of research partnerships with allied disciplines such as biology, zoology, ecology, agronomy and environmental science, such as in the emerging interdisciplinary field of 'critical zone science' (Anderson et al. 2010, Banwart et al. 2013, Brantley et al. 2016). However, if the geoscience community is to meaningfully address global sustainability issues, then even more ambitious and challenging collaborations will be needed, extending to the social sciences and humanities - human geography, anthropology, psychology, sociology, political science and law - which are concerned with the human dimensions and societal institutions whose values underlie our currently unsustainable ways of living (Stewart 2016, Stewart \& Gill 20217).
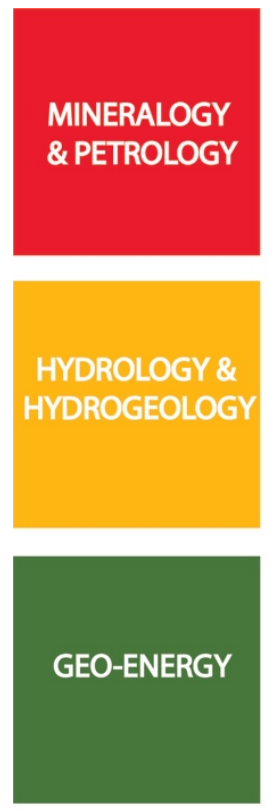
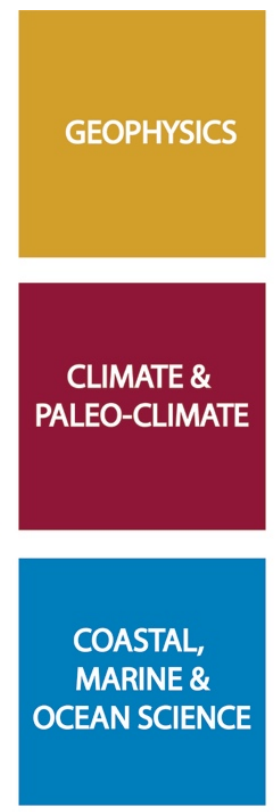
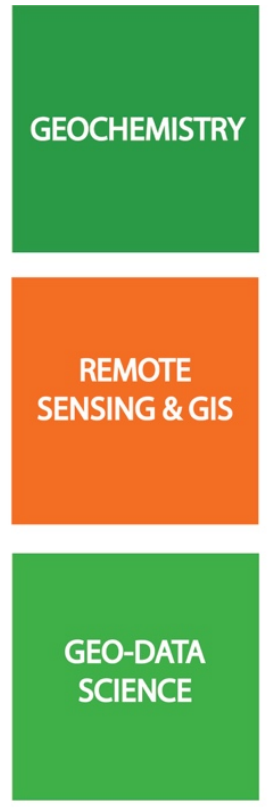
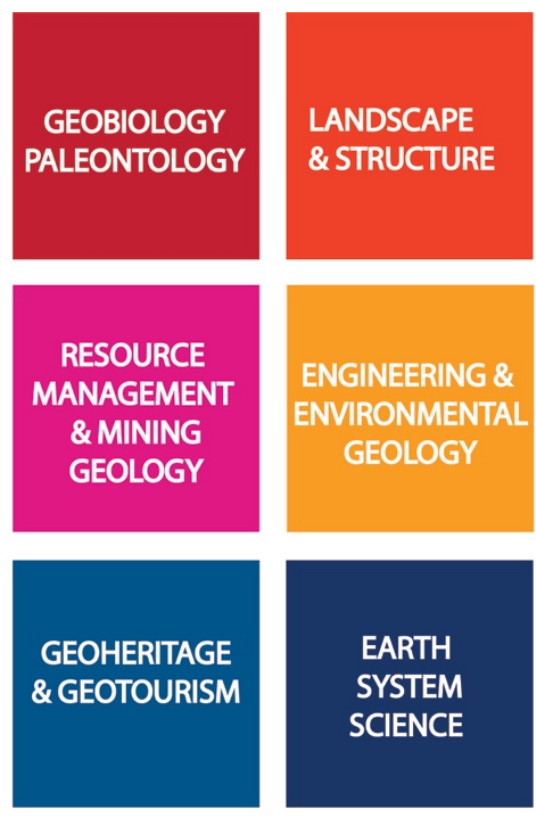
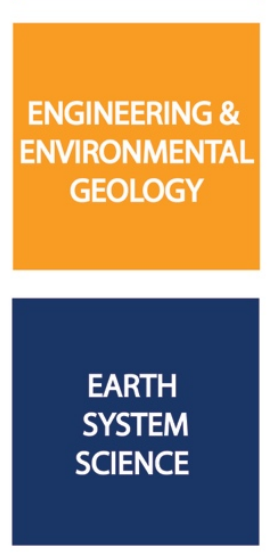
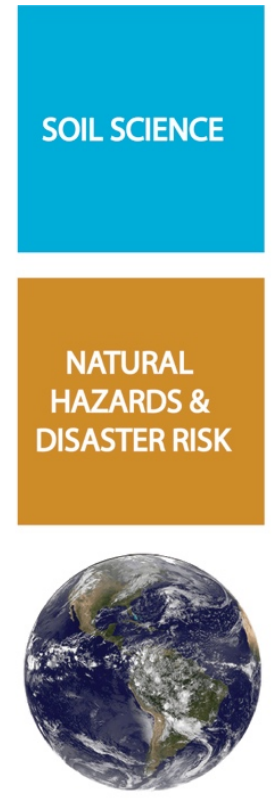

Fig. 5: Each of the main technical specialisms within geoscience have applications to helping tackle the challenges of sustainable development.

\subsection{The Education Challenge}


Geoscience's emboldened interdisciplinary inquiry will need to be rooted in teaching and learning that emphasises the interactions of geological, biological, chemical, and physical processes and environments, in combination with their social, economic, political and cultural dimensions - the realm of 'sustainability science' (Gosselin et al. 2020). By more directly addressing the formidable challenges of global unsustainability, traditional geoscience has the potential to be itself revitalized, at a time when recruitment to university geology and earth science courses around the world is struggling ${ }^{2}$. The promise is of a refreshed discipline - 'human geoscience' (Himiyama et al. 2020) - that is better fit for purpose in managing the pressing social and environmental concerns of sustainable development (Gill \& Smith 2021).

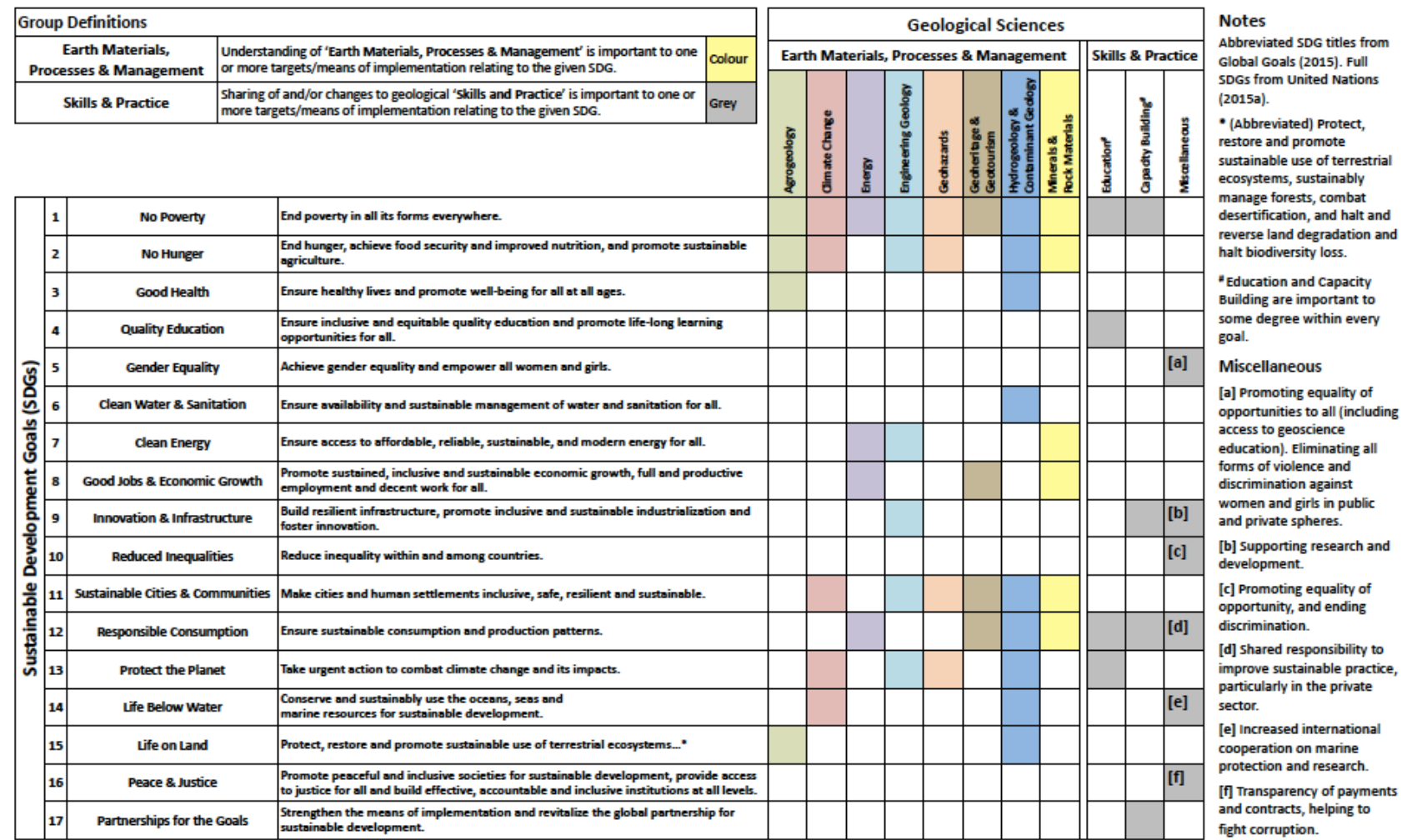

'Selway, K. 2021. 'Australia badly needs earth science skills, but universities are cutting the supply.' The Conversation, https://theconversation.com/australia-badly-needs-earth-science-skills-but-universities-arecutting-the-supply-163248; Geological Society of London report 'Enrolment in crisis: A UK-wide strategy for exciting, engaging and retaining students in the geosciences' https://www.geolsoc.org.uk/UniversityGeoscienceUKResources; Saucier, H. 2020. 'Geoscience Programs Evolve Through Declining Enrollment', AAPG Explorer (May) https://explorer.aapg.org/story/articleid/56972/geoscience-programs-evolve-through-declining-enrollment 
Fig 6. A matrix to visualise the role of geologists in helping to achieve the internationallyagreed Sustainable Development Goals (from Gill 2017)

Quite how this new pedagogic model of 'sustainable geoscience' can best be embedded into or grafted onto university geoscience courses and programmes will vary from country to country. In the USA, there is a long tradition in which 'sustainability is promoted as a strong organizing principle for modern liberal arts and technical education programs, requiring systems thinking, synthesis, and contributions from all disciplines - a geoscientists, natural/ physical scientists, social scientists, human and behavioural scientists, and engineers' (Gosselin et al. 2013). Here and elsewhere, geoscience courses are being restructured around the framework of the UN Sustainable Development Goals, the traditional emphasis on fossil fuel extraction rebadged as geoenergy or energy transition science, and, in the UK, the first chair in Sustainable Geoscience has been appointed ${ }^{3}$. In many universities, an introductory undergraduate course on 'Geology and Society' is a simple and obvious first step in helping students appreciate the relevance of their geoscientific training in the broad arena of sustainable development (Fig 6). At a more advanced level, and whilst maintaining the technical rigour and academic integrity of conventional geoscience training, applied courses on economic geology, petroleum geology and engineering geology can be reframed through a sustainability lens (e.g. natural resource management, geo-energy, urban geoscience). However, arguably the most transformative way for geoscience to integrate into sustainability science will be in developing bespoke postgraduate courses in sustainable geoscience that take advantage of interdisciplinary alliances within universities to establish Masters and PhD level training in a new holistic $21^{\text {st }}$ century Earth science thinking.

${ }^{3}$ Chris Jackson appointed as Chair in Sustainable Geoscience. https://www.manchester.ac.uk/discover/news/chris-jackson-appointed-as-chair-in-sustainablegeoscience/ 
There are broader win-wins to building sustainability into geology curricula and professional development training. It promises to develop a new generation of geoprofessionals well-versed in understanding and addressing sustainability issues (Mora 2013) and more able to effectively work with other scientists, business people, and politicians to develop viable solutions to current and future environmental and resource challenges. Graduate employability prospects will be further improved by stronger academic engagement on local environmental issues with external community-based stakeholders and the wider public. Finally, engaging with socially contested issues means dealing with ethical dimensions of sustainability (Metzger \& Curren 2017), which provides much needed ways to introduce geoscience students to the growing awareness of the principles and practices of geoethics, which are increasingly regarded as a vital component of professional geoscience practice (Peppoloni \& Di Capua 2016, 2021, Wyss \& Peppoloni 2014, Bohle \& Marone 2021).

\section{Concluding Remarks}

Reframing geoscience - and university geoscience education - around the grand challenges of the $21^{\text {st }}$ century would appear to be essential if Prince El Hassan's '3G' triangle of geography, geology and geophysics is to help guide the wise stewardship of the planet.

For geoscientists, sustainable geoscience has the potential to revitalize Earth science and re-connect it with its distant Huttonian roots. That wider re-enchantment could help reverse the current decline in geoscience student numbers at many universities around the world, and perhaps amerliorate the damaging association that the subject has with those vocational sectors that are now publically rejected as environmentally destructive, notably the fossil fuel and mineral extraction industries. 
The inclusion of socially-relevant modules or content in university courses could make geoscience more relevant to students who are fascinated by the planet but who do not pursue it, possibly because they see it as less salient, prestigious, or scientific than other disciplines, viewing it simply as 'the study of rocks' (Mora 2013).

Whether this re-purposing is for young students or senior decision makers, redefining James Hutton's social mission for the modern age will help society deliver its ambitious, enduring and motivating over-arching goal of long-term wellbeing for all (Stewart \& Hurth 2021), and in doing so show that $21^{\text {st }}$ century geoscience is more than simply the study of old stones. 


\section{ACKNOWLEDGMENTS}

This article began as a presentation in a 'Looking Forwards Backwards' seminar for British Institute in Amman's Council for British Research in the Levant (CBRL), and I appreciate the support and feedback of Carol Palmer, Nizar Abu Jaber and Matthew Jones. It has also benefitted from a range of activities relating to my new post as El Hassan Research Chair in Sustainability at the Royal Scientific Society, and the many conversations with RSS President HRH Princess Sumaya and with RSS Chairman HRH Prince El Hassan. Comments by Nizar Abu Jaber greatly improved the final manuscript. It is a contribution to UNESCO IGCP Project 685 on 'Geology and Sustainable Development' and part of the author's ongoing work as a UNESCO UNITWIN Chair in Geoscience and Society. 


\section{REFERENCES}

Anderson, S.P., Bales, R.C., and Duffy, C.J., 2008, Critical Zone Observatories: Building a network to advance interdisciplinary study of Earth surface processes. Mineralogical Magazine, v. 72, 7-10.

Baker, V.R., 2014. Uniformitarianism, earth system science, and geology. Anthropocene, 5, pp.76-79.

Banwart, S.A., Chorover, J., Gaillardet, J., Sparks, D. ,White,T., Anderson, S., Aufdenkampe,A., Bernasconi, S., Brantley, S.L, Chadwick, O., Dietrich,W.E., Duffy, C., Goldhaber, M., Lehnert, K., Nikolaidis, N.P, and Ragnarsdottir, K.V., 2013, Sustaining Earth's Critical Zone - Basic Science and Interdisciplinary Solutions for Global Challenges. The University of Sheffield, United Kingdom, 47p., ISBN: 978-09576890-0-8.

Bartos, P.J., Boland, M.A. and Freeman, L.W., 2006. The Human Face of Economic Geology: Education, Careers, and Innovation. Society of Economic Geologists Special Publication, 12, 171-19.

Brantley, S.A., DiBiase, R.A., Russo Tess, A., Shi, Y., Lin, H., Davis, K.J., Kaye, M., Hill, L., Kaye, J., Eissenstat, D.M., Hoagland, B., Dere, A.L., Neal, A.L., Brubaker, K.M., and Arthur, D.K., 2016, Designing a suite of measurements to understand the critical zone. Earth Surface Dynamics, v. 4, pp. 211-235, https://doi.org/10.5194/esurf-4211-2016.

Beer, T., Li, J. and Alverson, K. eds., 2018. Global Change and Future Earth: The Geoscience Perspective (Vol. 3). Cambridge University Press.

Bohle, M. and Marone, E., 2021. Geoethics, a Branding for Sustainable Practices. Sustainability, 13(2), p.895.

Burke, K.D., Williams, J.W., Chandler, M.A., Haywood, A.M., Lunt, D.J. and Otto-Bliesner, B.L., 2018. Pliocene and Eocene provide best analogs for near-future climates. Proceedings of the National Academy of Sciences, 115(52), pp.13288-13293. 
Calas, G., 2017. Mineral resources and sustainable development. Elements: An International Magazine of Mineralogy, Geochemistry, and Petrology, 13(5), pp.301306.

Capello, M.A., Shaughnessy, A. and Caslin, E., 2021. The Geophysical Sustainability Atlas: Mapping geophysics to the UN sustainable development goals. The Leading Edge, 40(1), pp.10-24.

Catana, M.M. and Brilha, J.B., 2020. The role of UNESCO global geoparks in promoting geosciences education for sustainability. Geoheritage, 12(1), pp.1-10.

Clark, W.C., Crutzen, P.J. and Schellnhuber, H.J., 2004. Science for global sustainability. Earth system analysis for sustainability. MIT, Cambridge, pp.1-28.

Cleland, C.E., 2001. Historical science, experimental science, and the scientific method. Geology, 29(11), pp.987-990.

Crutzen, P.J., 2016. Geology of mankind. In Paul J. Crutzen: A Pioneer on Atmospheric Chemistry and Climate Change in the Anthropocene (pp. 211-215). Springer, Cham.

Curtis, A., 2012. The science of subjectivity. Geology, 40(1), pp.95-96.

Davis, R., 2011. Inventing the present: historical roots of the Anthropocene. Earth Sciences History, 30(1), pp.63-84.

Dodick, J. and Orion, N., 2003. Geology as an historical science: Its perception within science and the education system. Science \& Education, 12(2), pp.197-211

Frodeman, R., 1995. Geological reasoning: Geology as an interpretive and historical science. Geological Society of America Bulletin, 107(8), pp.960-968.

Frodeman, R., 2014. Hermeneutics in the field: The philosophy of geology. In: The multidimensionality of hermeneutic phenomenology (pp. 69-79). Springer, Cham.

Gilbert, L., Teasdale, R. and Manduca, C., 2020. A New Vision of Sustainability in Earth Science Education. Eos, 101.

Gill, J.C., 2017. Geology and the sustainable development goals. Episodes, 40(1), pp.7076.

Gill, J.C. and Bullough, F., 2017. Geoscience engagement in global development frameworks. Annals of geophysics, 60. 
Gill, J.C., Mankelow, J. and Mills, K., 2019. The role of Earth and environmental science in addressing sustainable development priorities in Eastern Africa. Environmental Development, 30, pp.3-20.

Gill, J C. \& Smith, M. (Eds.) 2021. Geosciences and the Sustainable Development Goals. Springer.

Gosselin, D., Manduca, C., Bralower, T., Mogk, D. 2013. Transforming the Teaching of Geoscience and Sustainability. Eos, Vol. 94, No. 25, 221-222.

Gosselin, D.C., Egger, A.E. and Taber, J.J. eds., 2019. Interdisciplinary teaching about Earth and the environment for a sustainable future. Springer.

Himiyama, Y., Satake, K. and Oki, T. eds., 2020. Human geoscience. Springer.

Lambert, I.B. 2001. Mining and sustainable development: considerations for minerals supply. Natural Resources Forum, Vol 25, No. 4, 275-284.

Lucchesi, S., 2017. Geosciences at the service of society: the path traced by Antonio Stoppani. Annals of Geophysics, 60.

Ludden, J., 2020. Where is geoscience going?. Geological Society, London, Special Publications, 499(1), pp.69-77.

Kastens, K., C.A. Manduca, C. Cervato, R. Frodeman, C. Goodwin, L.S. Liben, D.W. Mogk, T.C. Spangler, N.A. Stillings, and S. Titus (2009), How Geoscientists Think and Learn, Eos Trans. AGU, 90(31), 265.

Kastens, K.A. and Manduca, C.A. eds., 2012. Earth and mind II: A synthesis of research on thinking and learning in the geosciences (Vol. 486). Geological Society of America Kastens, K.A., Agrawal, S. and Liben, L.S., 2009. How students and field geologists reason in integrating spatial observations from outcrops to visualize a 3-D geological structure. International Journal of Science Education, 31(3), pp.365-393.

Manduca, C.A. and Mogk, D.W. eds., 2006. Earth and mind: How geologists think and learn about the earth (Vol. 413). Geological Society of America.

Metzger, E.P. and Curren, R.R., 2017. Sustainability: Why the language and ethics of sustainability matter in the geoscience classroom. Journal of Geoscience Education, 65(2), pp.93-100. 
Mills, K. and Jones, M., 2021. Paleoscience and the UN sustainability goals. Past Global Changes Horizons, 1, pp.4-5.

Mora, G., 2013. The need for geologists in sustainable development. GSA Today, 23(12), pp.33-37.

Mudd, G.M., 2021. Sustainable/responsible mining and ethical issues related to the Sustainable Development Goals. Geological Society, London, Special Publications, 508(1), pp.187-199.

Peppoloni, S. and Di Capua, G., 2016. Geoethics: Ethical, social, and cultural values in geosciences research, practice, and education. Geological Society of America Special Papers, 520, pp.SPE520-03.

Peppoloni, S. and Di Capua, G., 2021. Geoethics as global ethics to face grand challenges for humanity. Geological Society, London, Special Publications, 508(1), pp.13-29.

Orion, N., 2006. Building an understanding of geological time: A cognitive synthesis of the "macro" and "micro" scales of time. Earth and Mind: How geologists think and learn about the Earth, 413, p.77.

Pennington, D., Ebert-Uphoff, I., Freed, N., Martin, J. and Pierce, S.A., 2020. Bridging sustainability science, earth science, and data science through interdisciplinary education. Sustainability Science, 15(2), pp.647-661.

Pratt, W., 1952, Towards a philosophy of oil finding: Bulletin of the American Association of Petroleum Geologists, v. 36, no. 12, p. 2231-2236.

Rajendran, C.P., 2019. Shifting Paradigms: Why History Matters in Geological Sciences. Current Science, 117(6), pp.927-931.

Reynolds, S.J., 2012. Some important aspects of spatial cognition in field geology. Earth \& Mind II: Synthesis of research on thinking and learning in the geosciences. Geological Society of America Special Publication, 486, pp.75-78.

Rockström, J., Steffen, W., Noone, K., Persson, Å., Chapin, F.S., Lambin, E.F., Lenton, T.M., Scheffer, M., Folke, C., Schellnhuber, H.J. and Nykvist, B., 2009. A safe operating space for humanity. Nature, 461(7263), pp.472-475. 
Rogers, R.D., 1989. Use of observational patterns in geology. Geology, 17(2), pp.131134.

Rogers, S.L., Egan, S.S. and Stimpson, I.G., 2018. Tracking Sustainability Concepts in Geology and Earth Science Teaching and Learning, Keele University, UK. The Journal of Academic Development and Education, (10).

Schlosser, P. and Pfirman, S., 2012. Earth science for sustainability. Nature Geoscience, 5(9), pp.587-588.

Schrodt, F., Bailey, J.J., Kissling, W.D., Rijsdijk, K.F., Seijmonsbergen, A.C., Van Ree, D., Hjort, J., Lawley, R.S., Williams, C.N., Anderson, M.G. Beier, P. et al. 2019. Opinion: To advance sustainable stewardship, we must document not only biodiversity but geodiversity. Proceedings of the National Academy of Sciences, 116(33), 1615516158.

Smelror, M. 2020. Geology for society in 2058: some down-to-earth perspectives Geological Society, London, Special Publications, 499, https://doi.org/10.1144/SP499-2019-40

Steffen, W., Persson, Å., Deutsch, L., Zalasiewicz, J., Williams, M., Richardson, K., Crumley, C., Crutzen, P., Folke, C., Gordon, L. and Molina, M., 2011. The Anthropocene: From global change to planetary stewardship. Ambio, 40(7), 739761.

Stewart, I., 2016. Sustainable geoscience. Nature Geoscience, 9(4), pp.262-262.

Stewart, I., 2020. Geology for society: Earth science for sustainable development. Humanistic futures of learning, p.39.

Stewart, I.S. \& Gill, J.C., 2017. Social geology—integrating sustainability concepts into Earth sciences. Proceedings of the Geologists' Association, 128(2), 165-172. Stewart, I.S. \& Lewis, D., 2017. Communicating contested geoscience to the public: Moving from 'matters of fact'to 'matters of concern'. Earth-Science Reviews, 174, 122-133. 
Stewart, I.S. \& Nield, T. 2013. Earth stories: context and narrative in the communication of popular geoscience. Proceedings of the Geologists' Association, 699-712. doi.org/10.1016/j.pgeola.2012.08.008.

Stewart, I.S. and Hurth, V., 2021. Selling Planet Earth: re-purposing geoscience communications. Geological Society, London, Special Publications, 508(1), pp.265283.

Stephenson, M.H., Cheng, Q., Wang, C., Fan, J. and Oberhänsli, R., 2020. Progress towards the establishment of the IUGS Deep-time Digital Earth (DDE) programme. Episodes, 43(4), pp.1057-1062.

Stillings, N., 2012. Complex systems in the geosciences and in geoscience learning. Geological Society of America Special Papers, 486, pp.97-111.

Wang, C., Hazen, R.M., Cheng, Q., Stephenson, M.H., Zhou, C., Fox, P., Shen, S.Z., Oberhänsli, R., Hou, Z., Ma, X. and Feng, Z., 2020. The Deep-time Digital Earth program: data-driven discovery in geosciences. National Science Review.

Wyss, M. and Peppoloni, S. eds., 2014. Geoethics: Ethical challenges and case studies in earth sciences. Elsevier.

Zalasiewicz, J., Waters, C.N., Williams, M. and Summerhayes, C.P. eds., 2019. The Anthropocene as a geological time unit: A guide to the scientific evidence and current debate. Cambridge University Press. 